\title{
POR UMA LITERATURA INFANTIL PORTUGUESA - AQUILINO RIBEIRO E MATILDE ROSA ARAÚJO
}

Luci Ruas

(Universidade Federal do Rio de Janeiro)

\section{RESUMO}

Meu propósito é mostrar que, no século XX, especificamente na sua segunda metade, muitos dos textos que se produzem para crianças já mostram evidente preocupação em descolar-se do destinatário, para que se dê importância ao como se constroem, isto é, para que a escrita se faça escritura e o texto literatura. Para isso, começamos por apresentar as preocupações de Antero de Quental e Eça de Queirós para depois abordar o trabalho literário de Aquilino Ribeiro, especificamente O romance da raposa, passando, em seguida à abordagem da obra de Matilde Rosa Araújo.

PALAVRAS-CHAVE: Literatura portuguesa para crianças; Aquilino Ribeiro; Matilde Rosa Araújo, século XX.

\section{ABSTRACT}

This work shows that, in the twentieth century, specifically in its second half, many of the texts produced for children already showed clear concern in separating itself from the receiver, so that value is given to how they are built, that is, so that from the writing scripture is made, and from text, literature. For this purpose, we start by presenting the concerns of Antero de Quental and Eça de Queiroz, and then approaching the literary work of Aquilino Ribeiro, specifically $O$ romance da raposa, following with the approach present in the literary work of Matilde Rosa Araújo.

KEYWORDS: Portuguese literature for children; Aquilino Ribeiro; Matilde Rosa Araújo; twentieth century. 
Ter imaginação é gozar de uma riqueza interior, de um fluxo ininterrupto e espontâneo de imagens [...] É ver o mundo na sua totalidade; pois o poder e a missão das imagens consistem em mostrar tudo o que permanece refratário. (ELIADE, 1979, p. 19)

Que menino se recusou já a brincar num sótão, a inventar inexistências? Está-se fora do mundo, numa torre inacessível, as pessoas crescidas ficam longe, com as suas ocupações, ideias, hábitos incompreensíveis. Aqui é o reino da fantasia, da realidade, indescoberta. (MIGUÉIS,1976, p. 126)

Não é minha pretensão, neste trabalho, levar a cabo uma história do livro e/ou da literatura para crianças em Portugal, mesmo porque não conto com tempo ou dados suficientes para fazê-lo. Meu propósito é mostrar que, no século XX, especificamente na sua segunda metade, muitos dos textos que se produzem para crianças já mostram evidente preocupação em descolar-se do destinatário, para que se dê importância ao como se constroem, isto é, para que a escrita se faça escritura e o texto literatura, "esse fluxo ininterrupto de imagens" capaz de se oferecer ao leitor de modo a provocar o prazer de descobrir "o mundo em sua totalidade, recriado pela linguagem”, manifestando-se criticamente em relação ao mundo em que vive.

Pelo menos desde as últimas décadas do século XIX, quando Antero de Quental publicou o Tesouro poético da infância, já se verificava a preocupação com a necessidade da leitura e da formação do leitor. O poeta é seguido de perto por Eça de Queirós, que, no artigo intitulado "O Natal - a 'literatura de Natal' para crianças” (26/12/1881), faz crítica ao que se publica em Portugal e refere-se à necessidade de que os livros estejam ao alcance das crianças, disponíveis para o manuseio. É certo que, desde o movimento romântico, Almeida Garrett já tinha mostrado preocupação com a alfabetização das crianças (a percentagem de analfabetos era, naquela época, altíssima) e com a melhora da situação dos professores das primeiras letras, desconsiderados e mal remunerados.

$\mathrm{Na}$ esteira da preocupação dos escritores dos oitocentos, o século XX faz-se pródigo em publicações para crianças, mas, como no Brasil do período pré-lobatiano, em Portugal multiplicam-se os textos cujo objetivo pedagógico ultrapassa em muito o da formação do leitor crítico e sensível à literatura e à arte, levando Natércia Rocha, no livro intitulado Breve história da literatura para crianças em Portugal a afirmar que "É preciso desescolarizar a leitura" (ROCHA, 1984, p. 12), no mesmo sentido em que Ana Maria Machado afirmara que "Cabe à literatura infantil ser literatura e não pedagogia” (apud KHÉDE, 1983, p. 11-12). Ressalve-se, no entanto, que é possível pensar uma pedagogia do texto e da leitura, se o marco a partir do qual a reflexão se desenvolva encontre seu ponto de apoio em pontos de vista como o de Maria José Palo e Maria Rosa Oliveira: 
Privilegiar o uso poético da informação é também pôr em uso uma nova forma de pedagogia que mais aprende do que ensina, atenta a cada modulação que a leitura pode descobrir por entre o traçado do texto. Ensinar breve e fugaz que se concretiza no fluir e refluir do texto, sem pretensões de ter a palavra final, o sentido, a chave que soluciona o mistério. Mais do que falar e preencher, o texto ouve e silencia, para que a voz do seu parceiro, o leitor, possa ocupar espaços e ensinar também. Redescobre-se, então, o verdadeiro sentido de uma acção pedagógica que é mais do que ensinar o pouco que se sabe, estar de prontidão para aprender a vastidão daquilo que não se sabe. A arte literária é um dos caminhos para esse aprendizado. (PALO; OLIVEIRA, 1986, p. 6-7)

Vista desta forma, a literatura infantil pode ser arte literária e, como tal, veículo fundamental e imprescindível para a construção do conhecimento sobre o si-mesmo e o mundo.

Desde as primeiras manifestações da modernidade, e mesmo antes (desde o século XVII procura-se padronizar uma literatura destinada à instrução das crianças burguesas), as funções da obra literária para a infância são ensinar e divertir, o que lhe confere um papel de utilidade. $\mathrm{O}$ que se realiza, nesse momento inaugural, é uma espécie de literatura capaz de formar um tipo de leitor cuja identidade acaba por convergir, de alguma forma, para os modelos que o seu grupo social deseja que permaneçam. Criar textos para a infância coincide, portanto, com o desejo de ensinar com competência, lançando mão, para isso, de mecanismos de sedução - como a manifestação do maravilhoso, a que a personalidade do leitor é sensível. Autoriza-se a invasão de sua privacidade, sob o pretexto de que os ensinamentos advindos da leitura serão competentes o suficiente para colaborar na sua formação. Ora, ensinar é uma coisa; conhecer é outra completamente diferente. A formação do leitor, nessa dimensão, parece fechar-se num universo formal em que ele é inscrito, como mantenedor de uma ordem sobre a qual não tem poder de interferir.

Sem pensar na singularidade das imagens criadas ao longo do processo de elaboração do texto, o escritor muitas vezes perde a oportunidade de apostar na construção de novas formas, já que imaginar admite a previsão dessa nova forma. Imaginar aí corresponderia a ter poder de transformar, mantendo a atualidade e a atualização constante das obras. Ter consciência desse poder transformador da linguagem significaria, portanto, admitir que os signos da linguagem estão em permanente rotação, permitindo a construção de novos sentidos para essas obras.

O século XIX, com Garrett, como já referimos, mostra o seu interesse e a sua preocupação em cuidar da produção de textos dedicados ao pequeno leitor. No entanto, embora os escritores dessa geração reconhecessem a importância de produzir esse tipo de textos, não conseguiram - talvez a época não o permitisse - estabelecer a diferença que existe entre a produção educacional, cujo interesse recaísse sobre o público infantil, da produção literária. É a geração de 70 que vai, porém, procurar alternativas para que o texto literário possa dirigir-se especificamente às crianças. 
Em seu Tesouro poético da infância (1883), Antero tece inúmeras considerações sobre a escola, a literatura, o leitor e a leitura. Pensa a possibilidade do prazer de ler, do prazer de aprender com e pela leitura, além de considerar as particularidades desse texto literário. E seleciona um conjunto de textos com os quais - acredita - as crianças possam se encantar, sem perder de vista, muitas vezes, a realidade que as circunda. Embora destine o livro às crianças, Antero não abre mão de, no Prólogo à edição, dirigir-se às mães, certo de que as crianças têm "tendências poéticas", de que a poesia "simples e elevada" pode contribuir definitivamente para o "carácter moral”. Ao mesmo tempo em que associa a leitura da poesia à formação moral, e, de alguma forma, atrelando a literatura a uma pedagogia, reconhece que o livro destina-se ainda à "leitura doméstica", tendo em vista a sua simplicidade, que contrasta com a "gravidade pedagógica" atribuída ao ensino. Não falta, nesse Prólogo, a crítica à escola, quando afirma que, "se não for jardim, será só prisão; a doutrina, se não for encanto, será só tortura”. Ainda que reconheça que a criança possui sensibilidade, que nela tudo é instinto e fantasia, as formas poéticas "podem envolver lição moral e até elevados conceitos racionais". Para o poeta, mesmo que simples e inspirada no popular, a poesia desenvolve e alimenta a sensibilidade, mas pode ser uma forma de conduzir à razão, ao bom comportamento, ao belo, ao bem, ao justo e ao verdadeiro, o que garante, aí, a sua utilidade. (QUENTAL, s.d., p. 7-15).

Da mesma forma, Eça de Queirós, no artigo já mencionado, com rara sensibilidade, e depois de tecer considerações acerca da celebração do Natal, da ceia natalina, da ansiedade das crianças pelos presentes que esperam receber, e do carinho dispensado ao "Papá Natal", concentra sua atenção nos livros que constituem a "literatura de Natal" para crianças. Critica os livros dos editores franceses, de "encadernações decorativas como fachadas de catedrais", muito mais úteis aos pais que às crianças, que, impedidas de tocar nas grandes figuras, contentam-se com vê-las de longe, sob o severo olhar as mães.

Não para, aí, todavia, a crítica do grande escritor. Reconhece que na Inglaterra é que existe uma "verdadeira literatura para crianças" e, com bastante lucidez, procura determinar os temas que mais agradam aos pequenos, de acordo com a idade e o que entende ser o nível do seu desenvolvimento: primeiro são os bebês e aqueles que se iniciam nas primeiras letras, a quem se dedicam livros ilustrados, com encadernações especiais e letras impressas em tipos enormes; depois, aos oito ou nove anos, chega a vez "das histórias de viagens, de caçadas, de naufrágios, de destinos fortes, a salutar crônica do triunfo do esforço humano sobre a resistência da natureza”.

Como escritor realista que é, Eça de Queirós não pode deixar de observar que tudo isto se apresenta às crianças de forma simples e clara, mas sem o recurso ao maravilhoso: "nem fantasmas, nem milagres, nem cavernas com dragões de escamas de ouro". Estes recursos, Eça afirma que se reservam à gente grande. Mesmo que essa literatura fale de anjos ou fa- 
das, certamente será para que as crianças possam "rir-se desse lindo sobrenatural". Assim, afirma o escritor, "as lições morais, que se dão desse modo, são inumeráveis, e tanto mais fecunda quanto saem da ação e da existência das coisas que melhor conhecem os seus bonecos". Mas tarde, aos cerca de quinze anos, será a vez da história, das ciências, textos em que "nem uma realidade muito crua ponha no espírito tenro securas de misantropia, nem uma falsa idealização produza uma sentimentalidade mórbida”.

Com o rigor da sua crítica em relação a Portugal, ácida e contundente, e depois de indagar se no Brasil existe isto, a literatura de Natal, Eça de Queirós afirma que, na Europa, particularmente na Bélgica, na Holanda e na Alemanha "prodigalizam estes livros para crianças", acrescentando que são "uma glória para a literatura" e, com aguda percepção de que este seria um grande filão, que, numa sociedade industrializada, traria muito lucro, "uma riqueza para o mercado". Antecipava, aí, o que Lobato diria anos mais tarde em carta a Godofredo Rangel, a propósito da literatura que se oferecia às crianças brasileiras. Assim se pronuncia o autor d' Os Maias, ao indagar ironicamente e ironicamente responder às suas indagações:

Eu às vezes pergunto a mim mesmo o que é que em Portugal leem as pobres crianças. Creio que se lhes dá Filinto Elísio, Garção, ou outro qualquer desses mazorros sensaborões, quando os infelizes mostram inclinação pela leitura. Isto é tanto mais atroz quanto a criança portuguesa é excessivamente viva, inteligente e imaginativa. Em geral, nós outros, os portugueses, só começamos a ser idiotas - quando chegamos à idade da razão. Em pequenos, temos todos uma pontinha de gênio [...] (QUEIRÓS, 2000, p. 1004-1006.)

Afora os comentários pouco elogiosos, é possível perceber que faltava muito ainda para que Portugal encontrasse a voz que trouxesse ao leitor criança o texto, que se preocupasse com o fazer escritural, capaz de provocar o prazer estético e a reflexão. Isto, apesar dos esforços de Antero, da crítica severa de Eça e da rara dedicação de João de Deus, com seus poemas povoados de melancolia, de gente triste e pobre, capaz de comover o leitor e acordar-lhe o olhar e o sentimento para as mazelas humanas, a despeito do que a crítica poderá chamar de paternalismo. Era o que o tempo e as convicções lhe permitiam. E, afinal de contas, não era mau que assim o fizesse, antecipando, tanto quanto o tempo lhe permitia, uma temática que viria a ser explorada mais tarde pela geração neorrealista.

Cabe ao século XX encontrar esse caminho e uma das primeiras vozes que se erguem para criar um texto em que o ensinamento moral cede ao lúdico, a sisudez do espírito ao sorriso de quem se delicia com a esperteza, nem sempre bem lograda, da raposa, a Salta-Pocinhas. Cabe a Aquilino Ribeiro (1885-1963) ser o "pai" da literatura portuguesa para crianças, quando, em 1924, publica o Romance da Raposa, e só é lamentável que Eça de Queirós não estivesse vivo para ver satisfeito o seu desejo (só que sem a preocupação moral), uma vez que Aquilino oferece a narrativa ao filho, como presente de Natal. 
Por isso mesmo fixamo-nos aqui na obra de Aquilino Ribeiro, ${ }^{1} \mathrm{o}$ "pai" da literatura para crianças em Portugal, pela publicação do Romance da raposa. Reforça o motivo da escolha o estudo desenvolvido por Francisco Topa (TOPA, 2014, p. 7), quando afirma os propósitos do autor, ao destinar as suas obras aos filhos e posteriormente à neta:

Ao contrário do que possa parecer, a referência à gênese destas obras de Aquilino Ribeiro representa um dado importante, antes de mais pelo que nos diz da sua concepção pessoal de literatura infantil. Com efeito, o simples facto de sabermos que a fonte germinal de tais obras foi o seu amor de pai e de avô permite-nos compreender por antecipação que se trata de trabalhos realizados de forma sincera e digna, em perfeita sintonia com o homem e com o escritor Aquilino. A simples presença quotidiana dos novos rebentos familiares constituiu, mais do que uma inspiração, um estímulo para que o autor empreendesse uma viagem ao fundo de si próprio e recuperasse as vivências e a sensibilidade do pequeno Amadeu, de Cinco Reis de Gente, que nunca deixou de ser, esse Amadeu que vivia em estado de permanente fascínio perante o inesgotável repertório de literatura oral da tia Custódia. (TOPA, 2014, p. 7)

Decerto, a memória das histórias ouvidas, do repertório popular, do conhecimento das fábulas de La Fontaine se entranha na obra de Aquilino, sem deixar de lado o caráter pitoresco, a mais autêntica alegria demonstrada por suas personagens, a despeito das mais retumbantes tragédias, o que provocou Óscar Lopes, fazendo-o comentar:

[...] há na literatura portuguesa uma grande carência de tudo o que seja expressão exuberante da simples alegria de viver, de viver, viver, mesmo apesar e através das maiores agruras ou tragédias. A saudade e a tristeza são o grande emblema da nossa lírica e da nossa novelística [...] A alegria em estado puro e ainda por cima bem consciente de si, a perfeita reconciliação com a natureza de que nascemos ou da natureza que connosco se descobre e refaz, ou seja, aquilo a que se chama o naturalismo do Renascimento, ou o aspecto por assim dizer solar (e não lunar ou sombrio) do naturalismo do séc. XIX, o próprio saborear da vitalidade humana a contas com as misérias e prepotências do mundo, tal como se espelha na novela picaresca espanhola, pode dizer-se que tudo isso irrompeu em força, e subitamente, nas letras portuguesas com Aquilino Ribeiro [...](LOPES, 1985, p. 10)

Creio poder afirmar sem receio de equívoco que, nos livros de Aquilino dedicados às crianças (e aí pouco importa se foram dedicados aos filhos e à neta), esse aspecto picaresco, revelado na irretocável figura da raposa - a Salta-Pocinhas - em suas aventuras; em sua crueldade sem remorso, na luta pela sobrevivência contra a tirania do lobo todo-poderoso; na trapaça contra o mais rico para defender a sobrevivência dos filhos; no espírito aventureiro que irrompe a partir do momento que tem que saltar 
as poças da vida para sobreviver. Na sequência do seu raciocínio, Óscar Lopes parece ratificar o meu ponto de vista:

Aquilino enxerta na velha cepa tão chorona da literatura portuguesa um género que ainda aqui não tinha pegado, apesar das suas excelentes provas em língua castelhana, e esse género é a novela picaresca, a história das aventuras, desgraças e ladinos expedientes de pícaros ou personagens populares, sem cultura letrada, sem arrimos sociais, mas férteis em manhas e dotados, como os gatos, de sete fôlegos e de resistência e de reactividade vital a toda a prova. (LOPES, 1985, p. 10)

Creio que vale a pena seguir as palavras de pórtico da narrativa, a dedicatória ao filho, ou "prefácio programático", como quer Francisco Topa:

As aventuras maravilhosas da Salta-Pocinhas - raposeta pintalegreta, senhora de muita treta - contei-tas, sentado tu nos meus joelhos. Contando-tas, veio-me a ideia de as escrever. Além de inspirador, colaboraste com teus silêncios, perguntas e interrupções na frágil meada. Que mais não fosse, só por este título o livrinho teria de levar o teu nome. Ao percorrer estas páginas, nos teus olhos em flor não virão brincar fadas $e$ duendes, bons gigantes e princesinhas. Tão-pouco ante eles se erguerão aqueles palácios encantados, que por serem de ouro e pedras finas, concebidos para satisfazerem a todos os desejos, tão diferentes são dos da terra. Que queres, no reino dos bichos não há nada disso, nunca houve. $\mathrm{O}$ doce mundo de ilusões, que o homem criou, reservou-o para figurantes, riscados, sim, pela fantasia, mas sempre à sua imagem e semelhança. Os chamados irracionais ali não têm ordem de entrar. Em harmonia, pois, com as leis da poesia e na ciência natural, não fiz da raposa princesinha. Personagem histórica, para mais, era meu dever não falsificá-la. Representa, tal como vem da fábula, no guinhol com os outros bichos, a todos os quais dei voz, com licença do mestre Esopo. E dei-lhes voz para melhor manifestarem o que são, e nunca para com eles aprendermos a distinguir bem e mal, aparências ou estados, pouco importa, atribuídos exclusivamente ao rei dos animais, como nos jactamos de ser.

Se ao fim de cada jornada, bateres as palmas, dar-me-ei por largamente recompensado. Basta que te recreies, como no jardim zoológico, para ambos não perdermos o tempo. Aí fica, meu homem, no teu sapatinho de Natal esta pequena prenda. Aceita-a com os meus beijos de pai, que ao Menino Jesus vou pedir perdão do pecado, pois que a raposa é matreira, embusteira, ratoneira, e ele apenas costumava brincar com pombas brancas e um branco e inocente carneirinho. (RIBEIRO, 1998, p. 7-9, grifos meus)

Sublinhei, nesse texto longo, mas necessário, aquilo que significa, na proposta de Aquilino, a sua novidade: a preocupação com a verossimilhança, quando afirma que os suntuosos castelos, as princesinhas e os 
duendes estão ausentes na sua narrativa por serem "tão diferentes dos da terra", e assinala a sua preferência pelo "mundo da natureza, e em particular pelo mundo da natureza animal"; o claro desejo de pôr em relevo o lúdico das cenas, em detrimento da lição que possam conter; a superação do maniqueísmo, lição nem sempre aprendida por outros escritores mais novos que ele e, ao contrário do seu projeto, atentos às moralidades; o respeito à tradição, com a vênia solicitada ao Pai da raposa - o velho Esopo -, mas sem a moral explícita das fábulas.

A "raposeta" aquilina não desdenha as uvas, tão somente porque não as pode alcançar. Ao contrário, utiliza-se da aguda esperteza, comum aos pícaros, para conquistar o que não tem, mesmo que isto custe a vida a outros. Os animais de Aquilino são projetados para serem o que são, e não mais. Mas o que mais me chama a atenção nessa dedicatória é a preocupação de provocar o prazer, gostosamente evocado nas palmas que o filho há de bater, ao ler cada aventura. Não, não é só isso: é mais, a prazerosa ironia com que pede perdão ao pecado de criar uma raposa que só é igual ao que dela já se sabe: que é matreira, embusteira etc., etc., etc., sugerindo que, oferecido como presente de Natal, o livro é uma verdadeira subversão à chamada "literatura de Natal", marcada pelas oposições radicais entre pobres e ricos, os premiados ou enjeitados pela sorte.

Moderno e crítico, Aquilino Ribeiro sabe que a literatura não tem que se subordinar ao Bem ou ao Mal, ao vício ou à virtude. Cabe-lhe criar um microcosmo em que tudo se faça encenação, dramática luta das figuras que assumem seus papéis na folha branca, como fingimento, como alimento do imaginário, como ficção. Juízos de valor, faça-os o leitor. Ele mesmo se posiciona criticamente, quando afirma em entrevista:

Perguntamo-nos se a criança tem necessidade de evasão como as criaturas de idade e batidas pelo uniforme pesadume das coisas. Por minha parte quero crer que o mundo gravita em sonho e mistério. Cada partícula da vida encerra um conto de fadas. Não é preciso inventá-las. (RIBEIRO, 1998, p. 174-175)

Ferindo a noção da harmonia das ações que acabam por constituir-se nos alicerces morais da sociedade burguesa, Aquilino não censura a raposa em suas trapaças, nem a transforma em metáfora do que o homem deve não ser para ser bom e justo. Sua humanidade consiste em lutar pela sobrevivência, nesse país sem fantasia, habitado pela raposa e pelo lobo, que ela destrona sem qualquer piedade (sátira ao poder instituído?). Um lobo predador, decerto, que não tem por ela qualquer compaixão, quando é acusada do crime de assassinato do Texugo, depois de a mãe e o pai Raposão lhe apontarem o caminho da rua, que ela deverá trilhar sozinha, lutando pelo pão de cada dia e pela sobrevivência. Primeiro, ainda sozinha; depois, mãe de família e com filhos. E nesse seu lutar não lhe escapa nem o bicho-homem. 
Talvez seja esta a ética da raposa: os fins acabam por justificar os meios de que se utiliza na busca da satisfação. Seu itinerário, o que se constrói desde as façanhas da jovem e arguta "raposeta pintalegreta, senhora de muita treta" estendendo-se ao tempo em que a vida já a transformara em "comadre cansada", mas não menos esperta e trapaceira. Nem por isso, todavia, deixa de preocupar-se com a formação da criança, leitor que deve fazer-se crítico: "Suponho que escrever para as crianças é uma pequena arte, bafejada por um Espírito Santo, pequeno e zombeteiro, que não será benéfico para toda a gente... nem por ventura para mim" (RIBEIRO, 1998, p. 172.)

Talvez seja essa estratégia o que faz da narrativa de Aquilino, um espaço vivo, dinâmico, em que o cômico se alia a uma percepção trágica da existência em que nem sempre o mais forte sai vencedor. A "raposeta" de Aquilino é astuta; sua trajetória é marcada pelo olhar tantas vezes irônico, mas bem humorado do narrador. Sabedor da sensibilidade da criança para os efeitos de linguagem, Aquilino explora esse filão, que já se percebe na dedicatória, quando apresenta a Salta-Pocinhas como "raposeta pintalegreta, senhora de muita treta". O recurso à rima, aos jogos verbais torna o livro rico de experiências linguageiras, fustigando, assim, o humor do leitor e chamando-o à coparticipação.

Posteriormente, Matilde Rosa Araújo (1921-2010), carinhosamente conhecida em Portugal como a "mãe" da literatura infantil, assim como Aquilino, criador da genial Salta-Pocinhas, cria uma obra em que o poético se sobrepõe ao pragmático e a linguagem instaura um universo mágico e sedutor. Tudo isto sem abrir mão, todavia, de pôr em xeque as metáforas do poder, seja ele qual for, e em que discurso se manifeste.

Escritora e pedagoga portuguesa, de seu nome completo Matilde Rosa Lopes de Araújo, nascida em 1921, em Lisboa, e falecida a 6 de Julho de 2010, na sua casa, em Lisboa. Tendo feito os seus estudos liceais com professores particulares, licenciou-se em Filologia Românica pela Faculdade de Letras da Universidade Clássica de Lisboa em 1945. Teve ainda uma apurada formação musical, com a frequência do Curso Superior do Conservatório da mesma cidade.

Ao contrário de Aquilino Ribeiro, cujo itinerário não se prende às funções de pedagogo, Matilde Rosa Araújo dedicou sua vida a escrever e a ensinar. Foi professora por muitos anos, dedicando parte dessa aventura à formação de professores, e fundamentalmente, mas não só, à literatura para crianças, com cujos problemas se preocupou e cujos direitos sempre defendeu. Construiu assim uma obra que se define como das mais importantes produzidas em Portugal, objetivando a infância e a juventude, quer do ponto de vista temático, quer do ponto de vista do protagonismo. Ao longo dos mais de cinquenta anos dedicados à literatura e à crítica, deixou algumas dezenas de livros publicados. ${ }^{2}$

Matilde Rosa Araújo entra no cenário da literatura para crianças em 1957, quando publica seu primeiro livro: O livro da Tila, conjunto de 
poemas que dá partida para a construção de uma obra que se organiza em torno de três grandes temas (conforme José António Gomes): "a infância dourada, a infância agredida e a infância como projecto” (1996, p. 250), além da própria vida da Tila, da infância à adolescência, no livro que se segue ao primeiro: $O$ cantar da Tila.

Em O livro da Tila, dá-se o primeiro encontro com o mundo, desvelado pela menina que, ao mesmo tempo se descobre, ora deslumbrada e feliz, ora vivendo o mesmo deslumbramento, mas convivendo com a solidão provocada pela perda desse universo que a encanta. De acordo com José A. Gomes,

O Livro da Tila desvela o universo de uma infância, em parte eufórico, feito de pequenos deslumbramentos perante o mundo e a natureza, expresso ora por um sujeito da enunciação infantil/juvenil, ora por uma voz adulta que observa o real e as relações que a criança com ele estabelece. (Idem, p. 252)

Exemplo dessa descoberta do mundo e da sua condição em face dele é o poema "Balada das vinte meninas friorentas". Resgatando, como em tantos outros poemas, o metro e o ritmo da poesia tradicional, fala-nos das aves que chegam com a primavera, armam seus ninhos e depois se despedem, com a ninhada, do inverno que chega.

Vinte meninas, não mais

Eu via ali no beiral:

Tinham cabecinha preta

E branquinho o avental.

Vinte meninas, não mais,

Eu via naquele muro:

Tinham cabecinha preta,

Vestidinho azul-escuro.

$[\ldots]$

As minhas vinte meninas,

Capinhas dizendo adeus,

Chegaram na Primavera

A acenarem lá dos céus.

$[\ldots]$

As minhas vinte meninas,

Com roupinha de cotio,

Chegaram na Primavera

Pois vinham fugindo ao frio.

Já passou a Primavera,

Suas horas pequeninas:

E houve um milagre nos ninhos,

Pois foram mães, as meninas!

[...] 
Já não são vinte meninas

Que a luz do sol acalenta.

São muitas mais! muitas mais!

Não são vinte, são oitenta!

Depois oitenta meninas

Eu via ali no beiral:

Tinham cabecinha preta

E branquinho o avental.

$[\ldots]$

Mas as oitenta meninas

Capinhas dizendo adeus,

Em certo dia de Outono

Perderam-se pelos céus.

$\mathrm{E}$ as minhas tantas meninas

Lá voaram, uma a uma:

E eu fiquei cheia de frio

E não voltou mais nenhuma

(ARAÚJO, 2010, p. 7-9)

Nesse poema, longo poema, que totaliza 17 estrofes (embora nem todas aqui transcritas), quadras escritas ao gosto popular, em versos de redondilha maior, o que garante à poesia de Matilde o seu apego ao metro tradicional e popular, é possível perceber o texto construído a partir do olhar da criança que, atenta às mudanças, descobre o passar do tempo e experimenta as suas perdas. As "minhas meninas", como as chama o sujeito enunciador, não lhe pertencem, embora, por algum tempo, delas se aproprie, reconstruindo-as pelo olhar pleno de afetividade, traduzida aí nos constantes diminutivos que as caracterizam. As aves animizam-se ao olhar atento da criança e com ela constroem uma espécie de harmonia cósmica. Chegam com a primavera, fugindo do frio. Aquecem-se, como aquecem o coração da menina Atravessam as estações - primavera, verão e outono. Procriam, para, no inverno, como as aves de arribação, procurarem outro conforto. É interessante assinalar o gesto metonímico da linguagem, quando a menina afirma que as aves "perderam-se pelos céus", deslocando de si mesma para o outro a consciência de perda. A menina aprende a experimentar a ausência, as perdas, tudo isso registrado na poesia. As experiências se acumulam, à passagem do tempo. Ficam-lhe as imagens construídas pelo olhar.

O aprendizado dos fenômenos do mundo exterior dá-se a partir da experiência afetiva, amorosa mesmo, que permite ao sujeito o sentimento de posse, não como poder de prender, mas como álbum de retratos armazenados pela memória, que recendem a um certo gosto a saudade.

No mesmo livro, a experiência também pode ser vivida pelo adulto que convive com a criança e nos dá notícia do seu dia a dia, já agora lembrando o Manuel Bandeira do poema "Debussy": 
Deixa contar...

Era uma vez

O Senhor Mar

Com muita onda...

Com muita onda...

E depois?

E depois...

Ondinha vai...

Ondinha vem...

Ondinha vai

Ondinha vem...

E depois...

A menina adormeceu

Nos braços de sua Mãe...

(ARAÚJO, 2010, p. 4)

Nesse poema, o ritmo ondulante, ou pendular, gerado pelos versos escritos em perfeito paralelismo, em que os verbos, sustentados pela cadeia fônica, configuram o vaivém das ondas, Matilde também constrói como que os movimentos de uma cantiga de ninar. Embalada pelo movimento do mar, imagem evocativa das cadeiras de balanço onde as mães embalavam os filhos, a criança adormece em ritmo lento, ondulante e musical.

Como em muitos outros poemas, de muitos outros livros - são mais de vinte -, Matilde Rosa Araújo parece encontrar o tempo da delicadeza, preenchido pelo traço fino e delicado a desenhar as imagens reveladoras do mundo desenhado por um olhar atento, sensível, inteligente, em que o humano é nota dominante. Por isso mesmo, não é sempre que seus poemas se fazem portadores de uma visão eufórica, embora não perca de vista essa euforia, de encontro feliz com a natureza, que se anima diante do olhar do leitor. Os que sofrem, os esquecidos da sorte ganham aí vida, num claro senso de justiça, como afirma José António Gomes, que atribui à autora "um olhar franciscano", cristão mesmo, sobre os homens e as coisas do mundo. É o que se pode verificar no conto "O menino dos pés frios", do livro $O$ sol e o menino dos pés frios (1972).

É inverno. Um menino, que tem os pés regelados, sem os poder agasalhar, entra numa bela casa onde uma mulher chora num canto, "triste e cansada". Um outro menino, que entrara na casa há dois mil anos - um dado de religiosidade na narrativa de Matilde, numa alusão ao Menino Jesus - volta à casa no dia do seu aniversário (é, portanto, como queria Eça de Queirós, uma "literatura de Natal") para dizer uma única palavra: AMOR. O menino nada tem de seu: nem casa, nem roupa, nem sapatos, nem lume. A mulher se envergonha. "Então ela consentia que na sua casa, na casa de todos, de tecto sempre azul, houvesse um menino sem roupa, sem lume, 
sem pão? Ela consentia uma coisa assim? E os outros também?” ARAÚJO, 1998, p. 10) - diz-nos o texto.

Ao indagar ao menino que caminho seguiria, se nada queria para levar, o menino lhe responde: “- Tens duas gotas de água nos teus olhos que reflectem o céu azul e a lâmpada do tecto. Não sentes?” As lágrimas correm pelo rosto da mulher e sua pele se torna "mais lisa", e ela, menos curva. A mulher descobre a necessidade de agir, de lutar contra o desânimo: "E a mulher entendeu que não adiantava chorar ao canto da casa. E o seu vestido era uma bandeira. E o seu coração uma flor. Com o menino ao seu lado." (ARAÚJO, 1998, P. 12) O apelo à ação, à luta, parece claramente enunciado. $\mathrm{O}$ compromisso com os desafortunados empurra o texto para uma dimensão social, que se enuncia sem que o texto perca sua força lírica. Publicado em 1972, o livro guarda, para além da religiosidade percebida, que faz da inércia ação e da roupa uma bandeira de luta, e a dois anos da Revolução dos Cravos, a memória recentíssima do pressuposto neorrealista: não basta ter consciência da realidade, muito menos chorar pela impotência. É preciso transformar a realidade. Cristã, fortalecida no apoio do Menino, a mulher parte, para fazer realidade um outro mundo.

Mais do que este sentido cristão que se apodera de alguns contos, porém, há uma sincera preocupação com os que sofrem, com os que a sociedade exclui e explora, diante de quem o narrador se envergonha ao descobrir a solidão, o abandono, e a quem pede perdão. $O$ poema que se segue é d'O cantar da Tila. Nele, a personagem experimenta o aprendizado da vida, na adolescência:

\section{APONTAMENTO}

Ó rapaz calado e pobre

Varrendo as folhas do chão:

A tua face descobre

$\mathrm{O}$ espelho da solidão.

Com teu carrinho de folhas,

Descendo pela avenida,

Se por acaso me olhas

Tenho vergonha da vida.

Diz que perdoas meu fato

Junto do teu abandono,

Moço de fato-macaco,

Que varres folhas de Outono.

(ARAUJO, 1986, p. 5)

A jovem Tila espelha-se no outro e em tudo percebe a diferença entre os dois: o trabalho, a roupa que veste, a pobreza, o que ocorre outras vezes, fazendo-a transformar-se franciscana e fraternalmente naquela que, 
seguindo o percurso do irmão do sol e da lua, dos animais e da natureza, deseja se aproximar dos pobres e dos humildes para fazer parte do seu mundo. O texto faz-se por meio de contrastes. A roupa da menina contrasta com o "fato-macaco" - o macacão, uniforme de trabalho - do rapaz. A jovem faz poesia; o rapaz é silêncio. É pobre, reflete a solidão. A jovem menina, porém, se o admira com o olhar compassivo, por outro lado experimenta o sentimento de vergonha pela injustiça que não pode combater senão pela denúncia, e a consciência de culpa, já que lhe pede perdão.

Em outro momento, a menina Tila experimenta o sentimento de amor pelos desafortunados. É o que se lê no poema que se segue:

\section{MEU PASTORZINHO}

Meu pastorzinho, sem estrela e sem gado,

Pudesses tu ser o meu namorado.

Meu pastorzinho, sem flauta e sem pão,

Pudesses tu ser o meu doce irmão!

Meu pastorzinho, sem Sol e sem Lua,

Se eu fosse apenas uma ovelha tua!...

(ARAUJO, 1986, p. 10)

A propósito desse poema, e das observações de Antonio j. Gomes, é possível afirmar que

Pelo discursivismo - e recorde-se a narratividade que caracteriza muitos dos seus poemas -, pelas ligações à tradição do nosso lirismo, a poética de Matilde partilha de um imaginário estético e até de uma concepção de poesia que, hoje em dia, consideraríamos, de certa forma, tradicionalizante. Não me parece, porém, que tal facto diminua o encanto de uma produção que soube fazer uma interessante síntese de correntes poéticas por vezes distantes. Em muitos textos, reflecte-se a herança neo-realista, na atenção ao real e à vida de personagens populares, e ocupações de ordem social e na confiança na possibilidade de uma vida nova [...] (GOMES, 1996, p. 252)

De fato, o poema, composto de três dísticos, se não apresenta a narratividade de outros, reflete a construção paralelística que evoca as cantigas de amigo, tanto ao dar voz ao feminino (a Tila é a voz que enuncia), quanto ao expressar o desejo de que o pastor seja o namorado pretendido ou o fraterno irmão, evocando então a herança franciscana. O olhar lírico comove-se com a pobreza e apela à comunhão humana. Se o humanismo fraterno e cristão preenche de ternura o espaço dos versos, por outro lado acorda o leitor para a necessidade de proximidade ao desfavorecido.

Mas não para aí a proposta poética de Matilde Rosa Araújo. Também se estende às narrativas em que se desmitificam antigos mitos de heroísmo e poder. Essas narrativas são publicadas num tempo em que a di- 
tadura e o silêncio que impunha às vozes libertárias já havia sido banido. Falo do livro $O$ cavaleiro sem espada, em que o cavaleiro caminha "por uma estrada de outono", cegamente e sem detença, "como se procurasse o Sol", montado num cavalo negro, prolongamento dele próprio, que, por isso mesmo, se veste também de preto.

Numa espécie de sortilégio, em que se retoma a velha tradição dos contos maravilhosos, quando dormir não significa apenas descansar e sonhar, mas cumprir o tempo que separa o herói de suas conquistas, o cavaleiro sente uma irresistível vontade de dormir. Amortece o galopar do cavalo, abranda o toque das esporas, apeia-se sem precisar prender a montaria, que, como seu dono, é obediente. Não sabe se o sono é sonho, se são lagrimas "que ele não sabia ou não podia chorar", ou "uma alegria serena por aquela paz de Outono a esperar o inverno frio" (ARAÚJO, 1979, p. 8). Talvez se reproduza aí o tempo do devaneio, entre sono e sonho, em que o poeta pensa e rumina o seu poema mais essencial.

Como se pode verificar, a narrativa ambienta-se num espaço que em tudo evoca os espaços medievais das novelas de cavalaria (a lembrança do Cavaleiro Negro de Herculano não seria de modo algum imprópria). O tempo é de outono. O cavaleiro corre, como à procura do sol, por uma estrada também "cheia de outono". Todavia, em vez de surpreender uma princesa adormecida, ou de lutar por ela contra a violência de usurpadores, ele é quem se surpreende com a chegada de um navio de velas de ouro, que, por isso mesmo, sobe pesado o rio. Dele desce, por um tapete vermelho, ao som de uma música triunfante, uma jovem muito bela, que descobre o cavaleiro adormecido e deseja, em vão, saber de quem se trata. “Tirando o cavalo e a árvore, é um homem muito só, vestido de negro, talvez filho da solidão." (ARAÚJO, 1979, p. 14) Poderosa, desconhecendo "que a vida é uma floresta feita de verdades e enganos" (ARAÚJO, 1979, p. 14), a jovem não sabe que "tem o poder de descobrir" (ARAÚJO, 1979, p. 15). Surpreende-se ao ver que o cavaleiro não se dobra ao seu olhar e à sua arrogância. Ali, naquele espaço, desfaz-se qualquer possibilidade de vassalagem. Esse Amadis não se dobra diante de Oriana. Sequer sabe se pode amá-la.

Em tudo, a jovem difere do cavaleiro: ele, despojado de qualquer riqueza, sem qualquer espada para qualquer guerra previsível, vem desarmado e deseja o sol; ela, rutilante de joias e de dourado, "dava a ideia de cortar a paisagem com uma espada de ouro e nada trazia nas mãos enluvadas". (ARAÚJO, 1979, p. 12)

Se a presença da jovem, aureolada pelo ouro e pelo desejo de poder aparentava e alimentava a presença de uma espada, o jovem cavaleiro, ao contrário, interroga: "Para que queria eu uma espada? Por que havia de ter uma espada? (ARAÚJO, 1979, p. 23) Afirma, assim, o seu despojamento, o seu desejo de amor e de justiça sem que, para tanto, tenha que cometer o crime do Cavaleiro Negro de Herculano, produto, também, de um desejo de justiça e de amor não cumpridos, que o leva ao presbitério e posterior- 
mente à luta contra a invasão da Península Ibérica pelos mouros e pela vitória do cristianismo que representa, em todos os casos impedindo-o de concretizar o amor pela sua Hermengarda. "Possa o sangue do Cavaleiro Negro remir os crimes do Presbítero" - é o que grita a personagem de Herculano diante da luta e da morte próxima, num gesto de abdicação da vida para tornar-se herói nacional.

Embora o cavaleiro negro tenha vontade de fugir ao olhar da rapariga coberta de ouro, enfrenta-a, quando esta lhe pergunta por que não tem uma espada nas mãos cobertas de luvas negras. Ao que responde o cavaleiro:

Nem espada, nem punhal, nem arma de fogo, nem uma faca do mato sequer. Estão nuas as minhas mãos debaixo das luvas negras. Tanta vez a solidão, a justiça não cumprida, o desejo de amor não deixa mostrar as mãos nuas, sem luva alguma e eu, no meu cavalo que tenho de esporear para correr o Mundo, ainda morro vivo desta solidão, deste desejo de justiça e amor não cumpridos. (ARAÚJO, 1979, p. 23)

À possibilidade de o cavaleiro tirar as luvas, supondo que, diante da moça, elas tenham o poder de sangrar, a jovem responde, assustada, que tem medo de sangue, gritando-lhe que pare com o seu "desejo horroroso" e desafiando-o: "Quem és tu, afinal, para me perturbares?" A lição que lhe dá o cavaleiro é a da inutilidade dos bens, que desaparecerão quando a jovem descer ao rio, de onde veio para se encontrar com o seu destino. É o que está em jogo nesse conto de Matilde Rosa Araújo: não a luta, não a identidade nacional, não qualquer invasão ou bandeira política. Mas um desejo de amor cumprido, que implica a aventura de ser e o humano desejo de completude.

A resposta da jovem é surpreendente: “- Não me importo de ver as tuas mãos. Tira as luvas. Se tuas mãos sangrarem, eu vou ao rio buscar água para lavar o teu sangue. Eu vou à floresta buscar bálsamo para curar tuas feridas." (ARAÚJO, 1979, p. 26) Mais surpreendente é descobrir que, tiradas as luvas, as mãos estão limpas de qualquer ferida. Tomada do desejo, sem barco nem ouro, sem culpa ou arrogância, nesse mundo desvendado e sem necessidade de "Persivais" ou "Excalibures" unificadoras, sem távola redonda ou pecado de perdição, a jovem pede para subir à garupa do cavalo e correr mundo em companhia do cavaleiro, que, em pleno Outono, fica "verde de Primavera".

Libertos da espada e do ouro, empreendem uma outra aventura, sobre a garupa de um cavalo que já não é mais negro, mas cinzento de tanto voar, e não tem mais antolhos. Constroem o seu próprio destino, à maneira das gaivotas, caminham em busca do seu próprio alimento. Montados na garupa do desejo, os dois jovens têm agora "mãos vivas" para segurar as rédeas da vida, "mão prontas para sangrar", como aponta o narrador. 
É desta forma que Matilde Rosa Araújo enfrenta mitos e tabus, em seu desejo de "justiça e amor não cumpridos". Nascidos do imaginário medieval, fixados ao longo dos séculos pela conservadora voz da tradição, esses mitos agora desfazem-se sob o poder da escritura renovadora de Matilde, sem medo das novas imagens que vão povoando o universo do leitor infante ou jovem, construindo uma nova imagem de mundo que cabe a esse leitor desvendar.

Decerto, a literatura que se escreve para crianças em Portugal não se limita aos seus "pais". Há inúmeros escritores que vão povoando o imaginário infantil de obras que também podem ser lidas por elas. Terá sido talvez indesculpável não tratar aqui de textos de Sophia de Melo Breyner, de Agustina Bessa-Luís, de Mário Cláudio, de Vergílio Ferreira, ou de José Saramago. Mas quis deter-me na consideração daqueles que praticamente iniciaram esse trabalho no século XX tornando realidade o desejo e a preocupação de Eça e Antero. Por isso mesmo aqui me detenho.

\section{REFERÊNCIAS BIBLIOGRÁFICAS}

ARAÚJO, Matilde Rosa. O cantar da Tila. 8 ed. Lisboa, Horizonte, 1986 (1. ed., 1967).

. O cavaleiro sem espada. Lisboa: Livros Horizonte, 1979. Ilustrações de Maria Keil.

O sol e o menino dos pés frios. Lisboa: Livros Horizonte, 1998

(1. ed. 1972.)

. O livro da Tila. Lisboa, Caminho, 2010. (1. ed. 1957).

ELIADE, Mircea. Imagens e símbolos. Lisboa: Arcádia, 1979.

GOMES, J. António. O universo poético de Matilde Rosa Araújo. Colóquio/Letras. Notas e Comentários, n. 140/141, p. 250-253, Abr. 1996.

KHÉDE, Sônia Salomão (Org.). Literatura infanto-juvenil: um gênero polêmico. Petrópolis: Vozes, 1983.

As polêmicas sobre o gênero. In: (org.). Literatura infanto-juvenil: um gênero polêmico. Petrópolis: Vozes, 1983, p. 9-18.

LOPES, Óscar. Um lugar de nome Aquilino. Colóquio/Letras, n. 85, maio de 1985.

MIGUÉIS, José Rodrigues. A Escola do Paraíso. Lisboa: Estúdios Cor; Círculo dos Leitores, 1976.

PALO, Maria José; OLIVEIRA, Maria Rosa. Literatura Infantil - Voz de criança. São Paulo: Ática, 1986.

QUENTAL, Antero de. Advertência. In: __. Tesouro poético da infância. Sintra: Colares Editora, s.d. (1 ed. 1883), p. 7-15. 
ROCHA, Natércia. Breve história da literatura para crianças em Portugal. Lisboa: Biblioteca Breve, 1984.

TOPA, Francisco. Em torno da Literatura Infantil de Aquilino Ribeiro. Disponível em http://web.letras.up.pt/ftopa/Artigos\%20Orais-Pdf/ Aquilino\%20Ribeiro.pdf, p. 7. Acessado em 10 de Julho de 2014.

QUEIRÓS, Eça de. O Natal - a "literatura de Natal" para crianças. In: _. Obra completa. Organização geral, introdução, fixação dos textos autógrafos e notas introdutórias de Beatriz Berrini. Rio de Janeiro: Nova Aguilar, 2000, p. 1100-1107.

Recebido para publicação em 05/05/2014

Aprovado em 07/09/2014

\section{NOTAS}

1 Aquilino Ribeiro escreveu quatro obras que visam ao público infantil, particularmente, e a princípio, a seus próprios filhos, que experimentaram com ele o gosto de ouvir histórias: Romance da Raposa (1924, dedicado ao filho Aníbal, então com 10 anos), Arca de Noé - III classe (1936, dedicado ao filho Aquilino), O Livro de Marianinha (escrito em 1962, mas publicado postumamente em 1967, e dedicado à neta Mariana) e Peregrinação de Fernão Mendes Pinto - Aventuras extraordinárias de um português no Oriente (esta última, adaptação da narrativa de viagens de Fernão Mendes Pinto às terras descobertas).

2 O Livro da Tila (1957), O Palhaço Verde (1960), O Cantar da Tila (poemas para a juventude, 1967), O Sol e o Menino dos Pés Frios (1972), O Gato Dourado (1977), Balada das Vinte Meninas (1977), As Botas do Meu Pai (1977), Camões Poeta, Mancebo e Pobre (1978), O Cavaleiro Sem Espada (1979), A Velha do Bosque (1983), O Passarinho de Maio (1990), Fadas Verdes (1994), Capuchinho cinzento (2005) são alguns desses títulos. 